\title{
A MISKOLCI EGYETEM A/2 ÉPÜLETE REZGÉSEINEK MÉRÉSE LÉ- ZERINTERFEROMETRIKUS MÓDSZEREKKEL
}

\author{
Béres Miklós \\ mérnöktanár, Miskolci Egyetem, Fizikai és Elektrotechnikai Intézet, Fizika Tanszék \\ 3515 Miskolc, Miskolc-Egyetemváros, e-mail: mechbere@uni-miskolc.hu \\ Jenyó Tamás \\ villamosmérnök, Miskolci Egyetem, Fizikai és Elektrotechnikai Intézet, Fizika Tanszék \\ 3515 Miskolc, Miskolc-Egyetemváros, e-mail: fizjetam@uni-miskolc.hu \\ Majár János \\ egyetemi docens, Miskolci Egyetem, Fizikai és Elektrotechnikai Intézet, Fizika Tanszék \\ 3515 Miskolc, Miskolc-Egyetemváros, e-mail: majar.janos@gmail.com \\ Paripás Béla \\ egyetemi tanár, Miskolci Egyetem, Fizikai és Elektrotechnikai Intézet, Fizika Tanszék \\ 3515 Miskolc, Miskolc-Egyetemváros, e-mail: fizpari@uni-miskolc.hu
}

\begin{abstract}
Absztrakt
Michelson típusú LIMA (Laser Interferometric Motion Analyser) és LDV (Laser Doppler Vibrometer) interferométereket használtunk a lézer laboratóriumunk falai igen gyenge (kisebb mint $1 \mu \mathrm{m}$ amplitúdójú) rezgéseinek méréseire. Azt találtuk, hogy a domináns komponens egy 6-7 Hz frekvenciájú rezgés, amit a teljes A/2 épület keresztirányú rezgéseként azonositottunk. Ezt a rezgést lokális tevékenységgel (pl. folyosón és lépcsön futkosással, ugrálással) nem tudtuk befolyásolni, de jellegzetes napi periodicitást mutatott, és volt kapcsolata a szélerösséggel is. A falak lokálisan is gerjeszthetö rezgései ettöl teljesen eltérö frekvenciájúaknak ( $k b .2,5 \mathrm{~Hz}, 30-40 \mathrm{~Hz}$, ill. kb. $60 \mathrm{~Hz})$ adódtak.
\end{abstract}

Kulcsszavak: Lézer Doppler rezgésmérés, épület rezgések, Fourier-analizis

\begin{abstract}
Michelson type (LIMA: Laser Interferometric Motion Analyser) and LDV (Laser Doppler Vibrometer) interferometers were used to measure the very week vibrations (less than $1 \mu$ m amplitude) of the walls of our laser laboratory. We found that the dominant component is a 6-7 Hz vibration, which was identified as the transversal vibration of the whole A/2 building. This vibration cannot be affected by local activity (eg. running and jumping around on the corridor or stairs), but it has a typical daily tendency, and it has a connection with the intensity of the wind, too. The wall vibrations that can be locally excited have quite different frequencies (approx. 2,5 Hz, 30-40 Hz, and approx. $60 \mathrm{~Hz}$ ).
\end{abstract}

Keywords: Laser Doppler vibrometry, building vibrations, Fourier analysis

\section{Bevezetés}

A ME Fizikai Intézetében a különböző mozgások kinematikai jellemzőinek precíziós mérésére többféle lézerinterferometrikus berendezés is rendelkezésre áll. Ezek egyikét a Wigner Fizikai Kutatóközponttal együttmüködve (beleértve a jogelődök, a KFKI SZFKI ill. NME együttmüködését is) fejlesztettük ki. 
Ez egy $0,1 \mu \mathrm{m}$ pontosságú lézerinterferometrikus mozgásanalizátor (LIMA = Laser Interferometric Motion Analyser), amely elsődlegesen elmozdulást mér, amelyből a további mozgásjellemzők (sebesség, gyorsulás) numerikusan származtathatóak.

A másik típusú lézerinterferometrikus müszerünk az LDV (Laser Doppler Vibrometer) elsődlegesen sebességet mér a Doppler-elv segítségével, a további mozgásjellemzőket ebből származtatja. A műszer érzékenysége alatta marad a LIMA-nak, de müködtetéséhez nincs szükség rezgésmentes asztalra. Mindkét detektor típus vezérlő programja rendelkezik gyors Fourier-analízis (FFT) funkcióval, a megfelelő rezgési spektrumok elóállíthatóak (Béres and Paripás, 2017).

Épületen belüli rezgéseket az LDV módszerrel már korábban is mértünk (Paripás et al. 2019). Ekkor Miskolc belvárosában egy, a Zenepalota közelében található műemlék jellegü épületben (Luther ház) mértük a villamosok elhaladása miatti rezgéseket. Azokban a mérésekben a 40-100Hz-es rezgések domináltak, amelyek a falak, ablakok, berendezési tárgyak rezgései voltak. Ismeretes, hogy az épületnek, mint egésznek ennél kisebb frekvenciájú (néhány Hz-es) rezgései vannak, a toronyházak rezgései pedig $1 \mathrm{~Hz}$ alattiak is lehetnek (Castellini, Martarelli, and Tomasini, 2013; Földrengések hatása épületekre n.d.). Ezeknek a mérése valamelyest eltérő módszert igényel.

\section{Mérési módszer}

A mi lézerinterferometrikus módszereink az alapmüszer és a fényt visszaverő felület relatív mozgását mérik. Ha az egész épület egyben rezeg (leng), akkor az épületen belül elhelyezett rezgésmérő müszerek (részben vagy egészben) átvehetik az épület rezgéseit, eltüntetve ezzel a relatív mozgásokat. Ezt legegyszerübben úgy kerülhetjük el, ha a müszereket rezgésmentes asztalra helyezzük el. Álló (nem rezgő) müszerekkel a fal rezgése pedig optikai módszerrel is jól követhető.

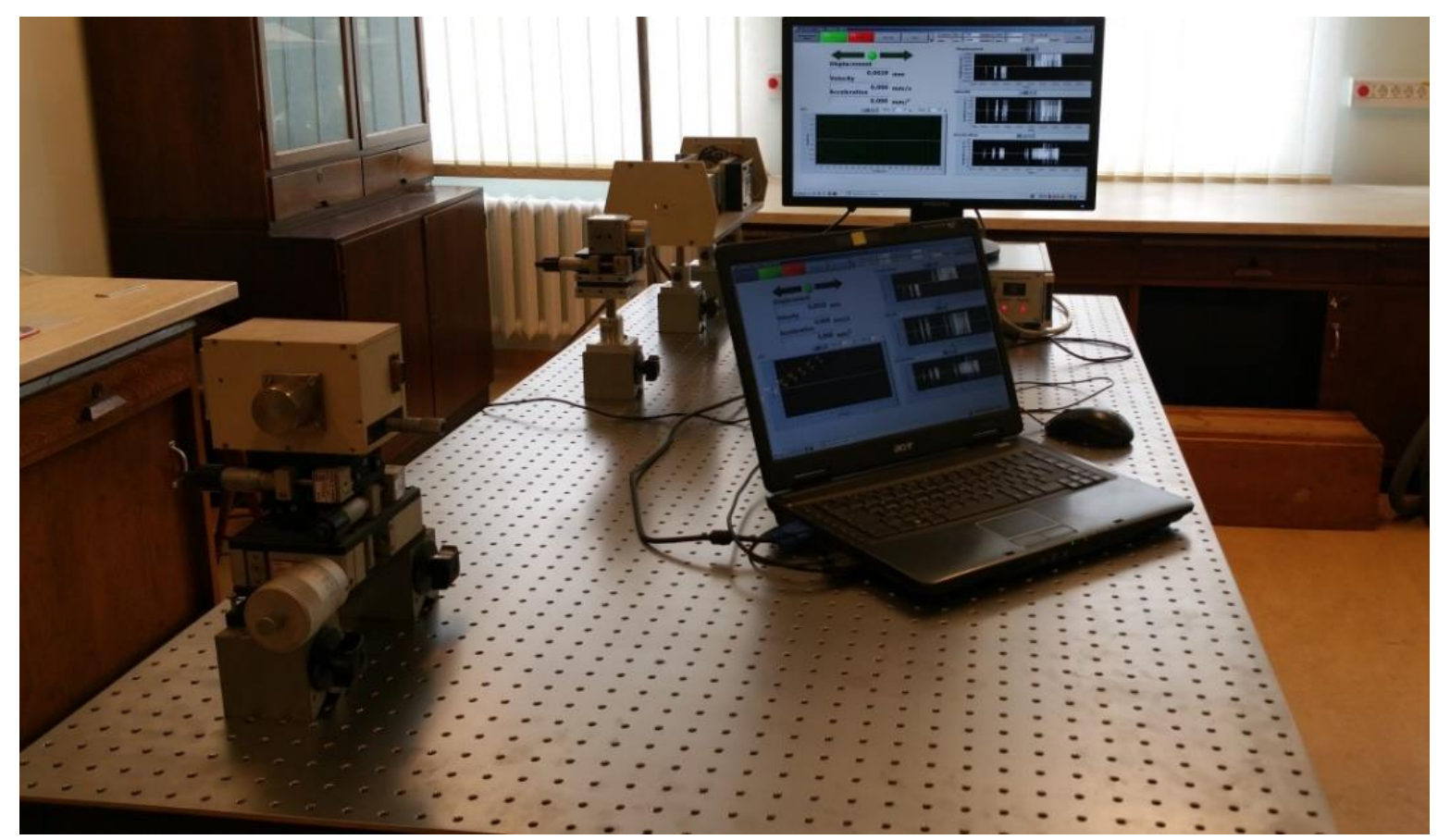

1. ábra. A lézerinterferometrikus mozgásanalizátor az új rezgésmentes asztalon müködés közben 

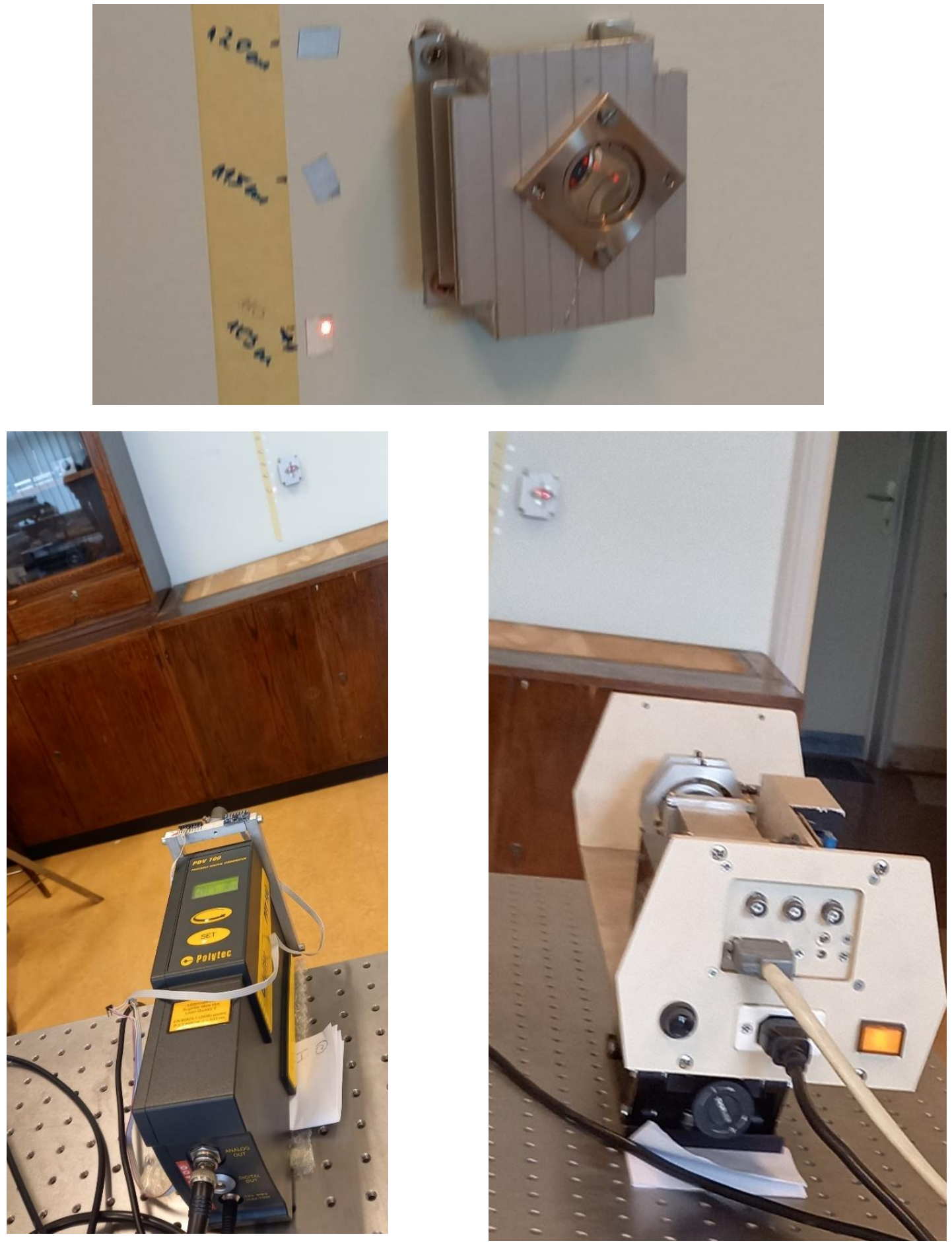

2. ábra. A rezgésmentes asztalon lévö LDV eszköz (balra lent), a LIMA eszköz (jobbra lent), valamint a falra erösitett méröoldali sarokprizma (LIMA) és visszaverö fólia (LDV) müködés közben (fent) 
A rezgésmentes asztal egy nagy tömegü, keresztirányú hegesztett kötésekkel merevített asztallapot jelent, amely az asztalkeretre rugalmasan támaszkodik. A mi esetünkben az asztallap egy Nexus Breadboard (900 x 1800 x 110 mm), amelyet az Exmet kiválósági programban (ME Fizikai Intézet, Wigner FK 2014) sikerült meg vásárolnunk. Ezt egy saját gyártmányú asztalkereten helyeztük el. Az asztallap és az asztalkeret között légrúgók vannak (4 db felfújt kismotor belső gumi). Az így kialakított rezgésmentes asztal a környezet rezgéseinek amplitúdóját könnyedén a lézerinterferometrikus mozgásanalizátorunk mérési határa, azaz $0,1 \mu \mathrm{m}$ alá csökkenti (1. ábra).

A LIMA-val és LDV-vel történő mérések elvét a (Béres and Paripás, 2017) és (Castellini et al., 2013) irodalmakban már részletesen ismertettük. A mérések helyszíne értelemszerủen a Fizikai Tanszéknek az a laboratóriuma, amelyben a rezgésmentes asztal (rajta a LIMA készülékkel) elhelyezésre került. Ez az A/2 épület III. emeletének 10. szobája. Jelen mérések során mindkét müszer a rezgésmentes asztalon volt elhelyezve, kivéve a LIMA mérőoldali sarokprizmáját, amelyet a falra csavaroztunk fel. Ez a fal amelyen tehát az első méréseket végeztük - a laboratóriumnak a folyosó oldali tartófala. Közvetlenül a sarokprizma mellől a falról verődik vissza az LDV lézernyalábja is (2. ábra). A két eszközzel különkülön és szimultán is tudjuk mérni ennek a falnak a rezgéseit. Hangsúlyozandó, hogy a lézerinterferometrikus módszerek csak a lézersugár irányú rezgéseket mérik. Jelen mérések során tehát a falnak a saját síkjába eső (tehát hosszirányú) rezgései rejtve maradnak.

\section{Mérési eredmények}

\subsection{LIMA mérések}

Az első méréseket egy (időjárási és forgalmi szempontból is) csendes napon délelőtt végeztük el. A LIMA-val végzett 100 s-os mérés időspektruma a 3. ábra felső felében látható, alatta pedig ennek egy 5 s-os kinagyított részletét láthatjuk.
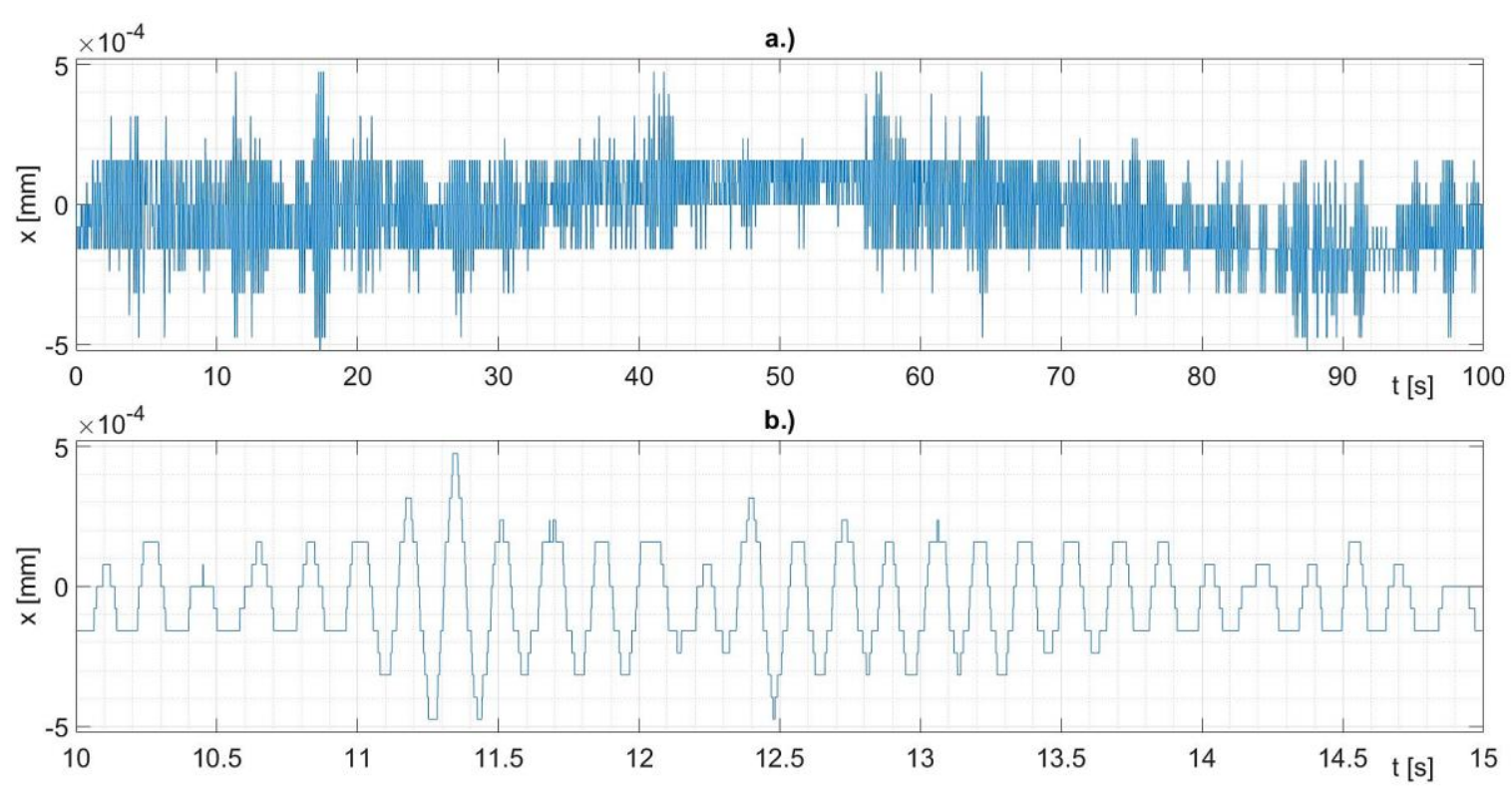

3. ábra. A falrezgés LIMA-val mért időspektruma (elmozdulás-idö függvénye) és annak egy kinagyitott szakasza (lent) csendes laboratóriumban 
A hosszabb időspektrum egy viszonylag szabálytalan rezgés képét mutatja, amelynek még a középpontja is tolódik kissé. A rövidebb spektrum viszont jól mutatja, a szabályosságot is, vagyis azt, hogy az időspektrumot egy kb. $6 \mathrm{~Hz}$-es rezgés dominálja. Az ábrák lépcsős szerkeze annak köszönhetö, hogy a müszer az elmozdulást $\lambda / 8$ egységekben méri (ami 79,1 nm-nek felel meg) - látsd (Béres and Paripás, 2017; Loughridge and Abramovitch, 2013). Jól látható, hogy a rezgés amplitúdója néhány egység csupán, alatta marad a fény hullámhosszának, azaz a nem interferencián alapuló optikai módszerekkel egyáltalán nem lennének mérhetőek.

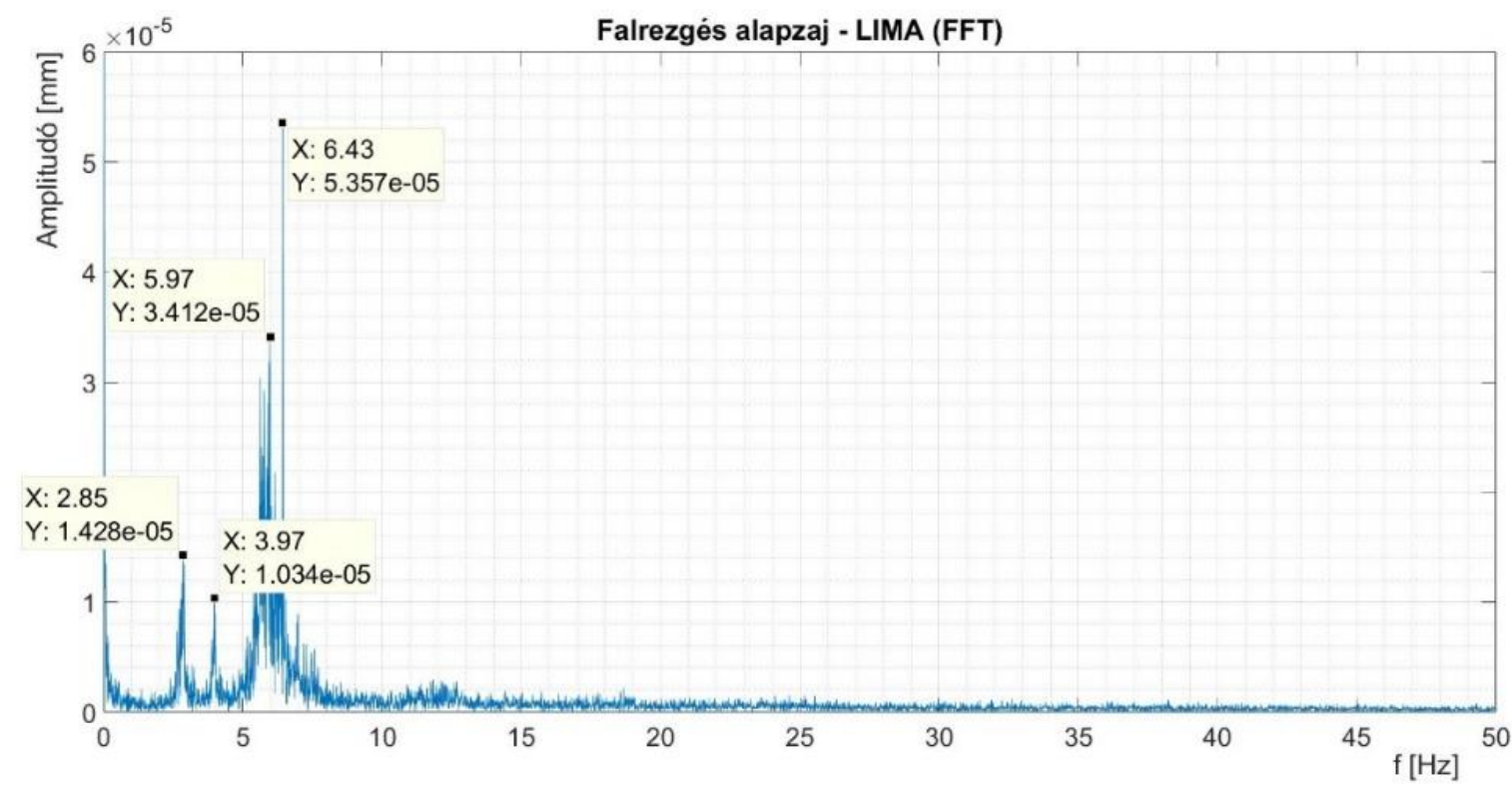

4. ábra. A falrezgés LIMA eszközzel mért FFT spektruma (a 3. ábrán bemutatott idöspektrumhoz tartozó FFT spektrum) csendes laboratóriumban

A falrezgés FFT spektruma (4. ábra) is jól mutatja a $6 \mathrm{~Hz}$ körüli rezgések dominanciáját. Ez nem egy éles rezonancia, a félérték szélessége $1 \mathrm{~Hz}$ körül van. Kisebb rezonanciák 3 és $4 \mathrm{~Hz}$ környékén is vannak, de nagy komponens van $0,1 \mathrm{~Hz}$ alatt is. Az utóbbi komponens az igen lassan változó rezgési középpont következménye, amit minden bizonnyal a hőtágulás okoz. A felhasznált FFT program a spektrális komponensek amplitúdóit 6·10-5 $\mathrm{mm}(=0,06 \mu \mathrm{m})$ alá teszi. Megjegyezzük, hogy ezek az értékek a vonatkozó szabványban (MSZ 18163-2:1998, Rezgésmérés. Az emberre ható környezeti rezgések vizsgálata építményekben, 1998) szereplő értékek ezredrészét sem érik el. Tehát igen messze vannak attól, hogy ezeket az ember érzékelje, vagy az épület állagát veszélyeztessék.

A laboratóriumban és környezetében végzett tevékenységek (beszélgetés, séta a folyosón, szomszédos helyiségben lévő eszterga bekapcsolása) alig befolyásolták a rezgési képeket. A folyosón és a lépcsőkön történő ugrálás, futkosás hatása azonban már látható volt (5. ábra és 6. ábra). Ez az ugrálás, futkosás azonban a domináns $6 \mathrm{~Hz}$ körüli rezgésekre nem volt hatással, hanem a kisebb 2-3 Hz közötti rezgések amplitúdóját növelte meg, akár a domináns rezgés amplitúdója fölé is. A folyosón történő ugrálás gerjesztett egy gyenge $30-40 \mathrm{~Hz}-\mathrm{es}$ rezgést is. 


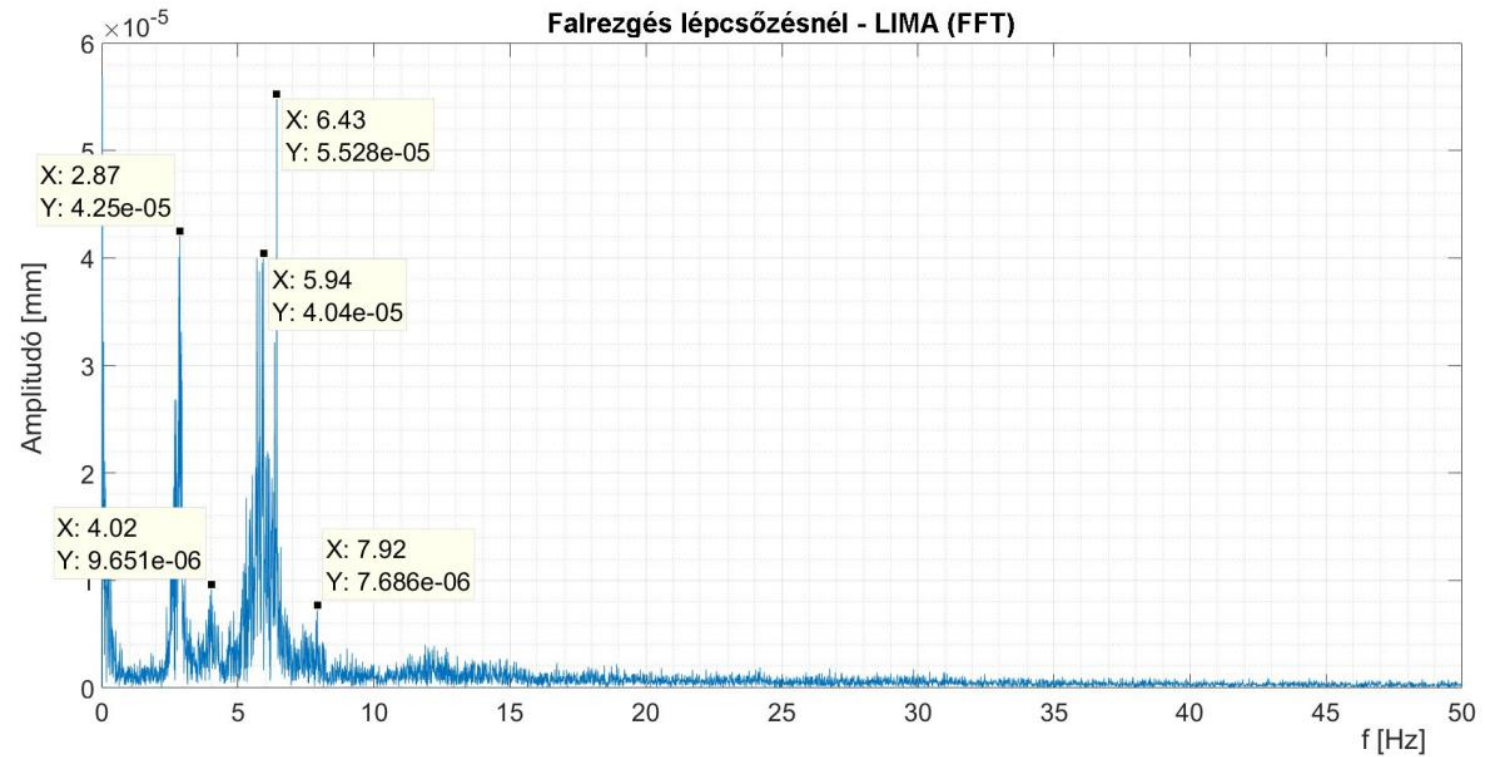

5. ábra. A falrezgés LIMA eszközzel mért FFT spektruma, ha a kb. 10 méterre lévö lépcsön ugrálnak

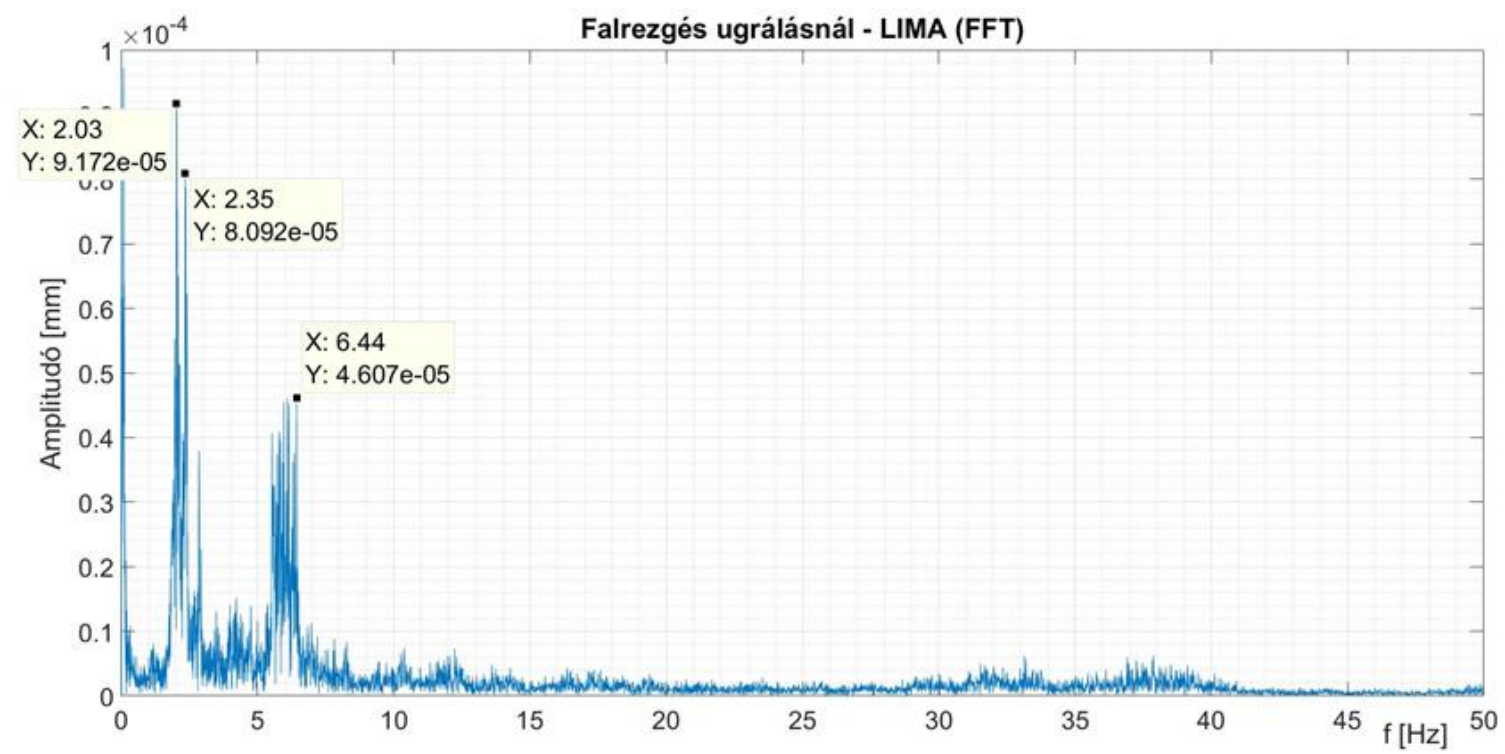

6. ábra. A falrezgés LIMA eszközzel mért FFT spektruma ha a laboratórium elötti folyosón ugrálnak

\subsection{LDV mérések}

Ahogy a bevezetésben is utaltunk rá, ezzel a módszerrel elsődlegesen sebességet mérünk. Közismert, hogy azonos amplitúdójú rezgések esetén a nagyobb frekvenciájú rezgéshez nagyobb sebességek $\left(v_{\max }=A \cdot \omega\right)$ tartoznak. Tehát az LDV módszer (a LIMA-hoz képest) a $0 \mathrm{~Hz}$ körüli rezgéseket nem tudja jól mérni, a nagyobb frekvenciájú jeleket viszont kiemeli. Másrészről az LDV eszköz belsejéből jön egy 
kb. 4 kHz-es rezgés is, minden bizonnyal a Bragg-cella müködése miatt. Az látható minden LDV spektrumban, de olyan messze esik a vizsgált 0-100 Hz tartománytól, hogy a mérést érdemben nem zavarja. Megjegyezzük, hogy a $4 \mathrm{kHz}$-en mért 0,055 mm/s sebességhez csupán 1-2 nm-es amplitúdó tartozik, tehát ezt a rezgést a LIMA már elvben sem tudja mérni.

A csendes laboratóriumban mért LDV spektrumban is jól láthatóak az épület kb. $6 \mathrm{~Hz}$-es lengései (a már említett $4 \mathrm{kHz}$-es müszer rezgés mellett), de a kisebb, 3-4 Hz-es rezgéseket ez a módszer már nem tudja kiemelni (7. ábra).

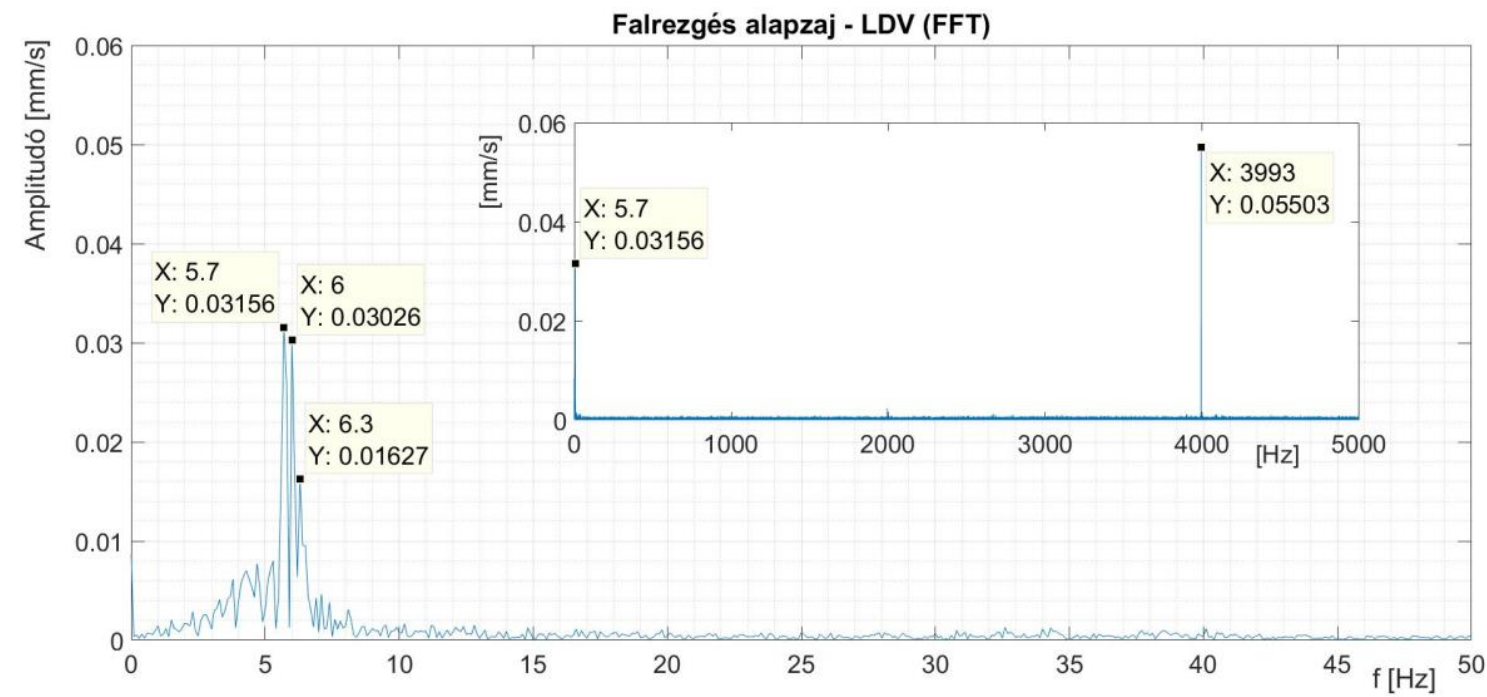

7. ábra. A falrezgés LDV eszközzel mért FFT spektruma (belül a teljes spektrum, kívül a 0-50Hz tartomány kinagyítva) csendes laboratóriumban

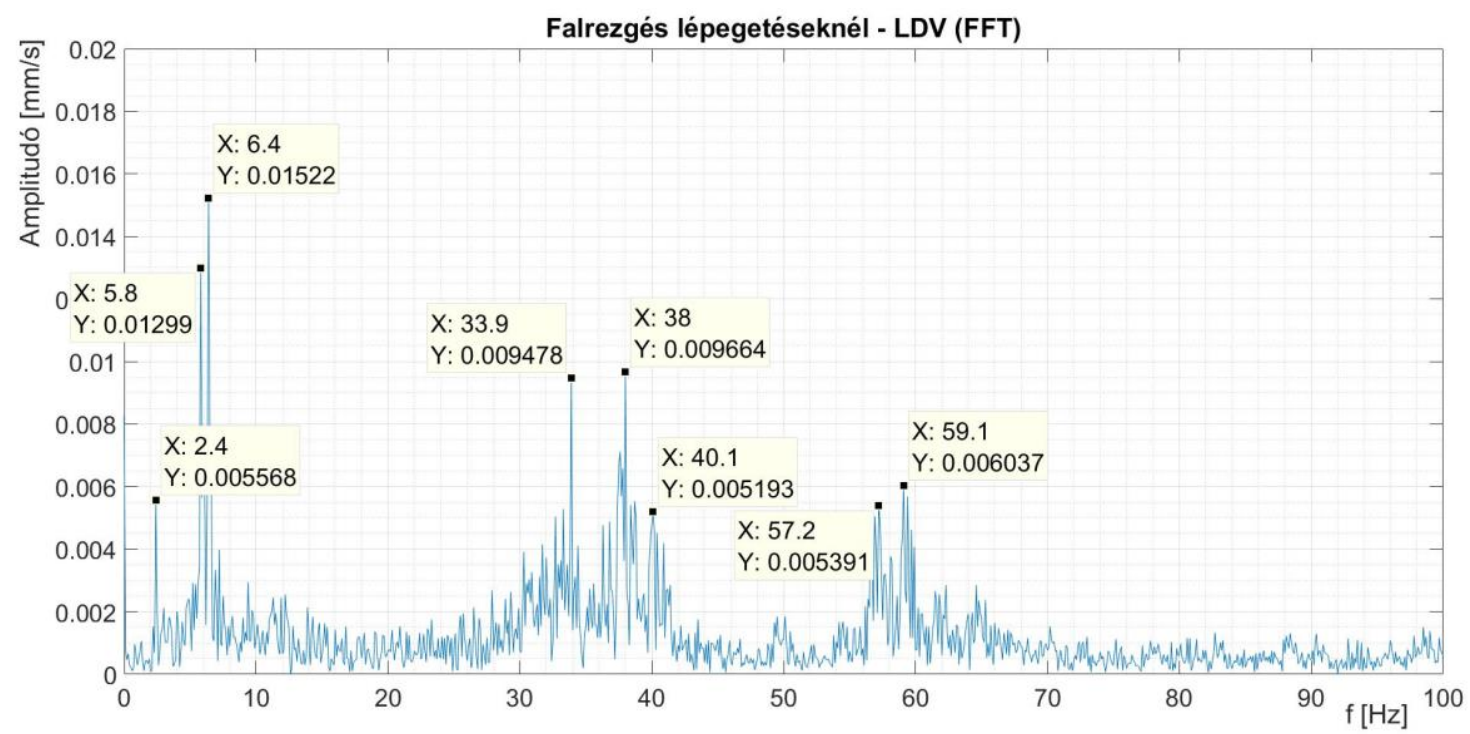

8. ábra. A falrezgés LDV eszközzel mért FFT spektruma ha a laboratórium elötti folyosón ugrálnak 
A folyosón történő ugrálás, futkosás hatására az LDV spektrumban is megjelenik egy éles $2 \mathrm{~Hz}$-es és egy 30-40 Hz-es rezgés is. Ez utóbbi értelemszerüen jobban látszik itt, mint a LIMA spektrumban (8. ábra). Sőt ebben a spektrumban egy $56-60 \mathrm{~Hz}$-es rezgés is láthatóvá válik.

Az LDV módszerrel lehetőség van a laboratórium többi falának a tanulmányozására is. A külső tartófal (amelyen az ablakok is vannak) ugyanúgy leng, mint a belső (folyosó oldali) tartófal, amit a 7. ábra mutat.

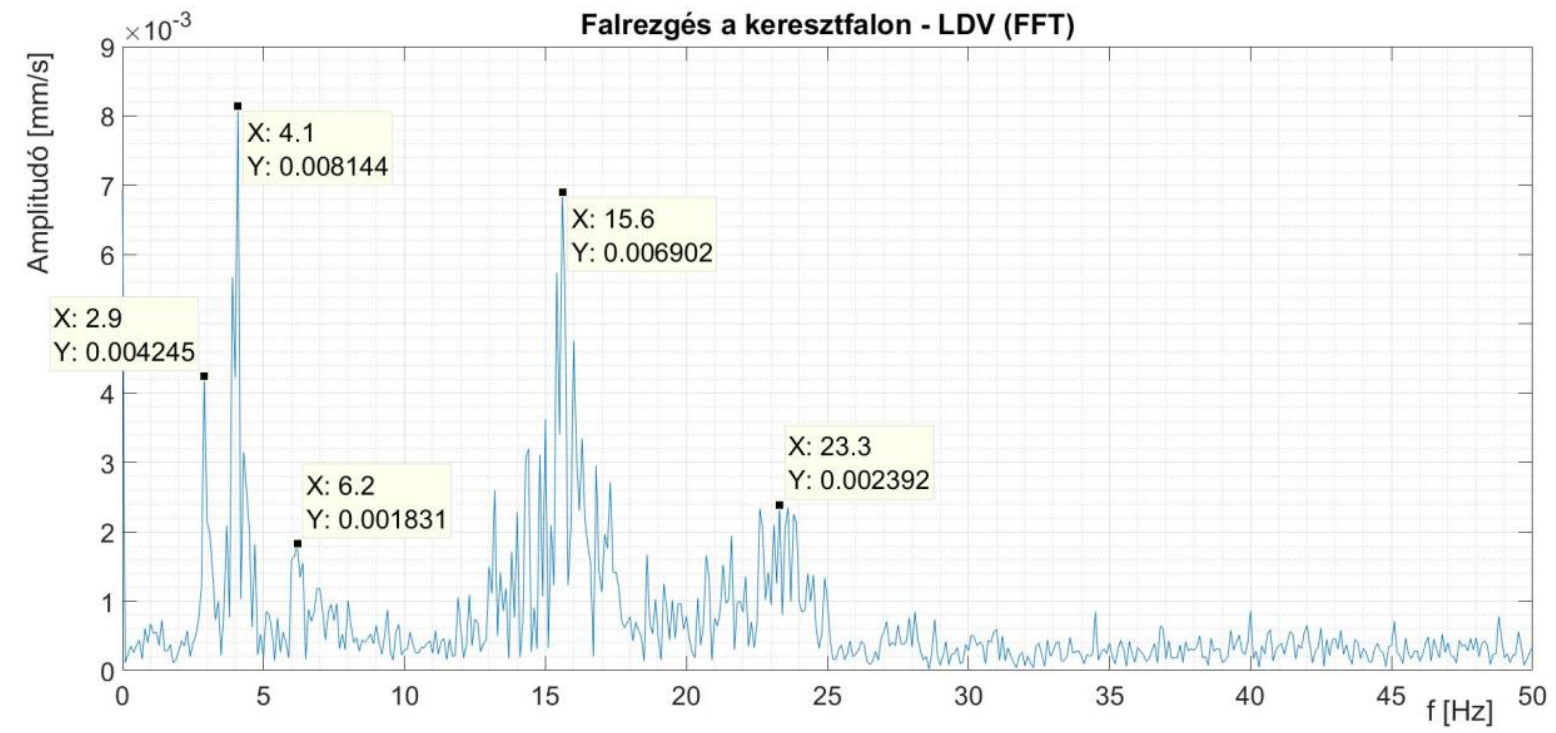

9. ábra. A keresztfal rezgés LDV eszközzel mért FFT spektruma csendes laboratóriumban

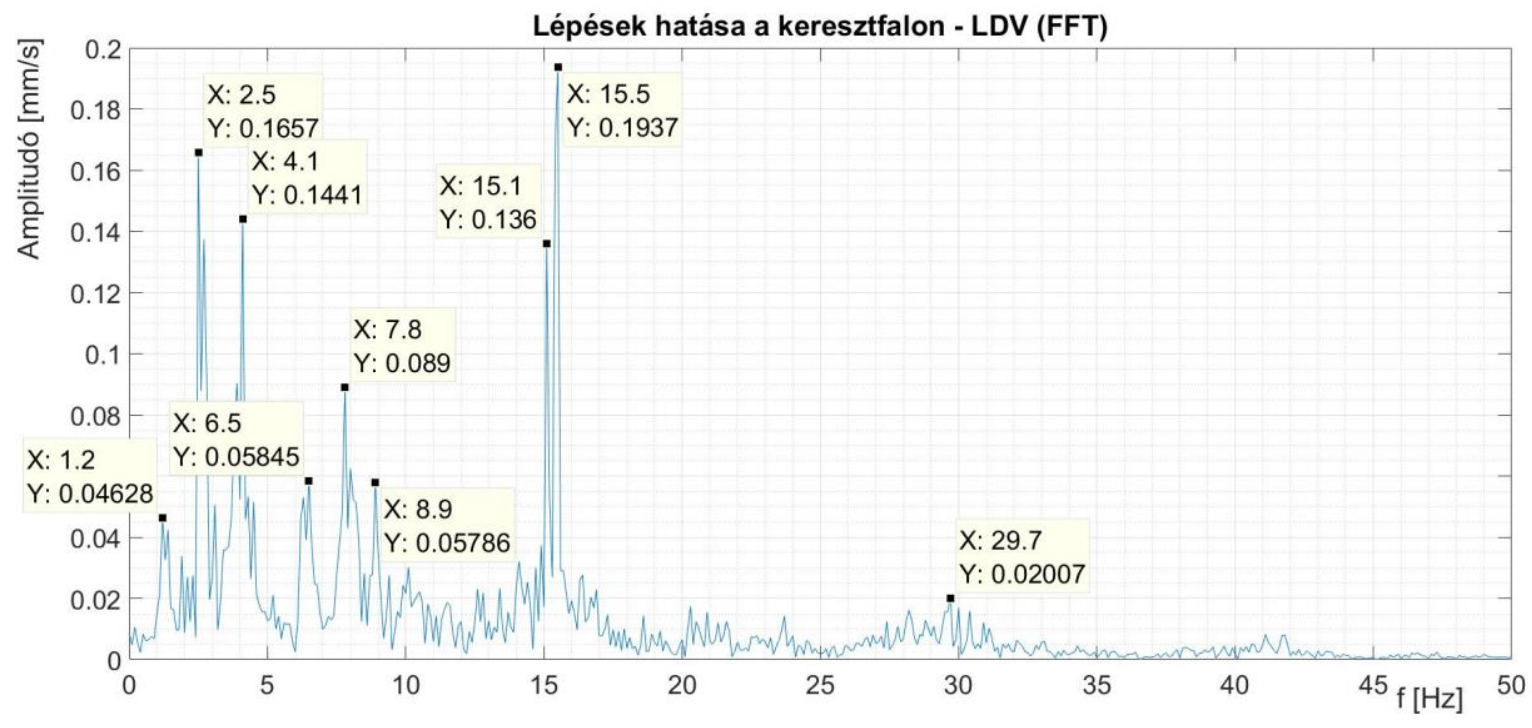

10. ábra. A keresztfal rezgés LDV eszközzel mért FFT spektruma, ha a folyosón fizikai aktivitás (ugrálás, futkosás) van 
A két tartófalat összekötő keresztfalak rezgései azonban teljesen más spektrummal bírnak (9. ábra). Ez persze nem meglepő, hiszen ezek a rezgések az épület hossztengelye irányába mutatnak, tehát merőlegesek a főfalakon mért rezgésekre. A spektrumban itt nyoma sincs a $6 \mathrm{~Hz}$ körüli csúcsnak, viszont egyértelmü csúcsok vannak 3-4 Hz, 15-16 Hz és $23 \mathrm{~Hz}$ környékén.

A folyosón történő fizikai aktivitás (ugrálás, futkosás) azonban sokkal nagyobb hatással volt a keresztfal rezgéseire, mint az őt határoló tartófaléra. Az amplitúdó növekedés néhány frekvencián (3-4 Hz és $15-16 \mathrm{~Hz}$ ) több mint egy nagyságrend (10. ábra).

Másképpen fogalmazva a keresztfal csendes környezetben mért rezgései eltörpülnek a fizikai aktivitás esetén mérhető rezgések mellett.

Több héten át folyamatosan mértük a tartófal rezgéseit. Tíz másodperces időspektrumokat vettünk fel, ezeket Fourier-analízissel kiértékeltük. A kapott FFT spektrumokban meghatároztuk a maximális amplitúdót és az ahhoz tartozó frekvenciát. A 11. ábra az egy héten át (2021. július 12. (hétfő) 0 órától 18. (vasárnap) 24 óráig) kapott maximális amplitúdókat ábrázolja. A könnyebb kezelhetőség és a kiértékelési hibák csökkentése érdekében az amplitúdókat 12 adatonként ( 2 percenként) átlagoltuk.

Érdemes megjegyezni, hogy a héten végig napsütéses, frontmentes idő volt, de hétvégére megérkeztek a felhők és vasárnap délután az eső is.

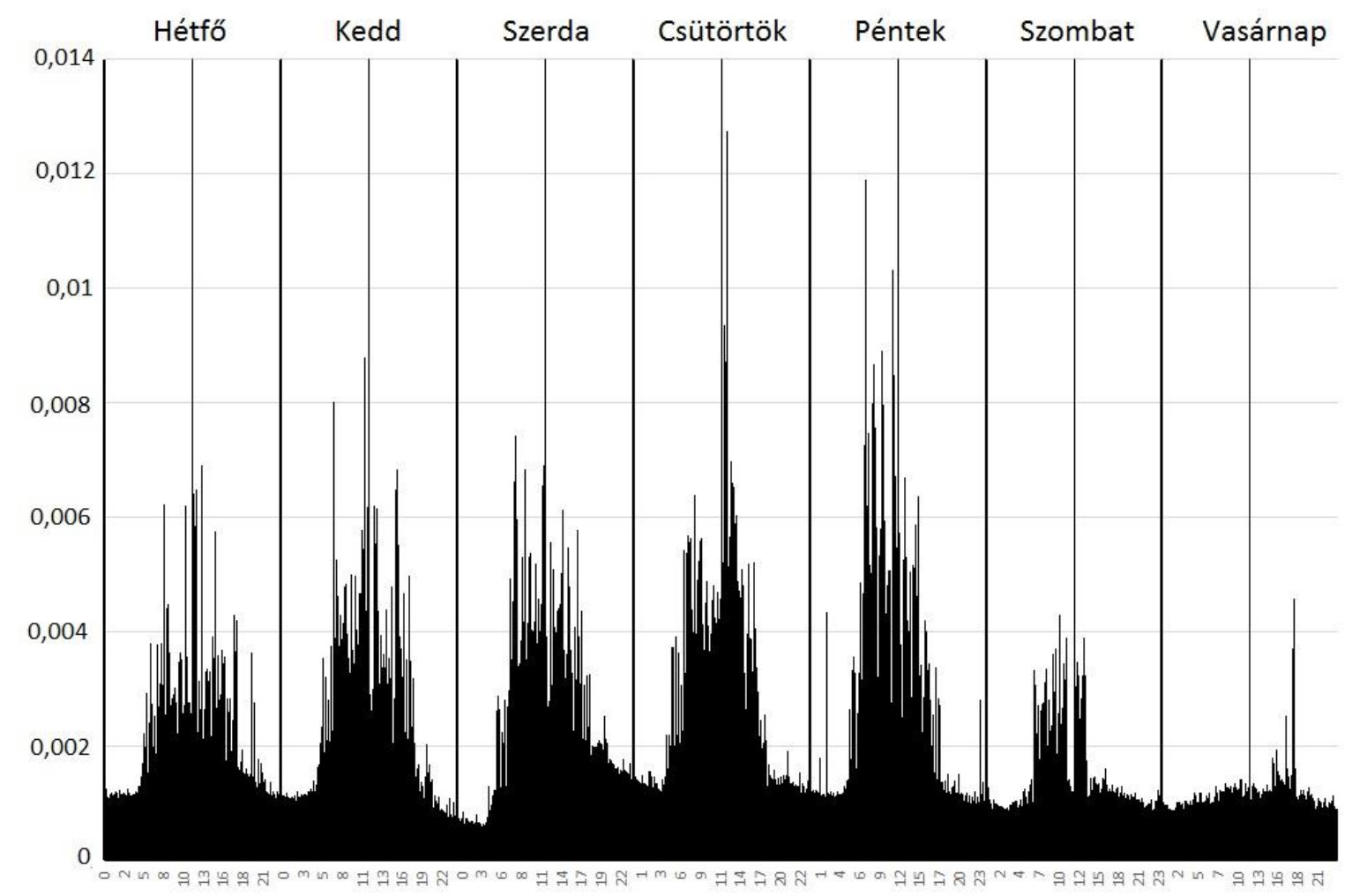

11. ábra. A tartófal rezgés $L D V$ spektrumainak maximális amplitúdói $\mathrm{mm} / \mathrm{s}$ egységben. Kétperces átlagok 2021. július 12. (hétfó) 0 órától 18. (vasárnap) 24 óráig (a vastag függöleges segédvonalak az éjfélt, a véknyak a delet mutatják) 
A rezgési (sebesség) amplitúdóknak jellegzetes napi menete volt. Éjszaka általában kicsik voltak az értékek (kb. $0,001 \mathrm{~mm} / \mathrm{s})$, a minimumokat hajnalban érte el. Nappal sokkal nagyobbak voltak az amplitúdók, a hétköznap mindig elérték a $0,006 \mathrm{~mm} / \mathrm{s}-$ os maximumot. A hétvégi nappalokon (különösen vasárnap) azonban kevésbé rezgett az épület. Ebböl az egyheti adatsorból nem dönthető el, hogy ezt a jellegzetes napi menetet, ill. a hétköznap-hétvége különbséget mi okozta. Ez az ok lehet például az épületben lévők fizikai aktivitása, ami munkaidőben nyilván nagyobb. De okozhatják meteorológiai tényezők is. Például a szélerősség, ami napsütéses, frontmentes időben nagyon hasonló tendenciával rendelkezik (éjszaka minimális, a déli órákban maximális). Szerepe lehet a széliránynak is, az épületre meröleges légáramlás nagyobb keresztirányú rezgéseket okozhat. A napsütés nemcsak szeleket generálhat, hanem speciális épületen belüli ill. épület körüli áramlásokat, amelyek szintén rezgéseket kelthetnek. E kérdés tisztázása érdekében jelenleg is folynak a mérések.

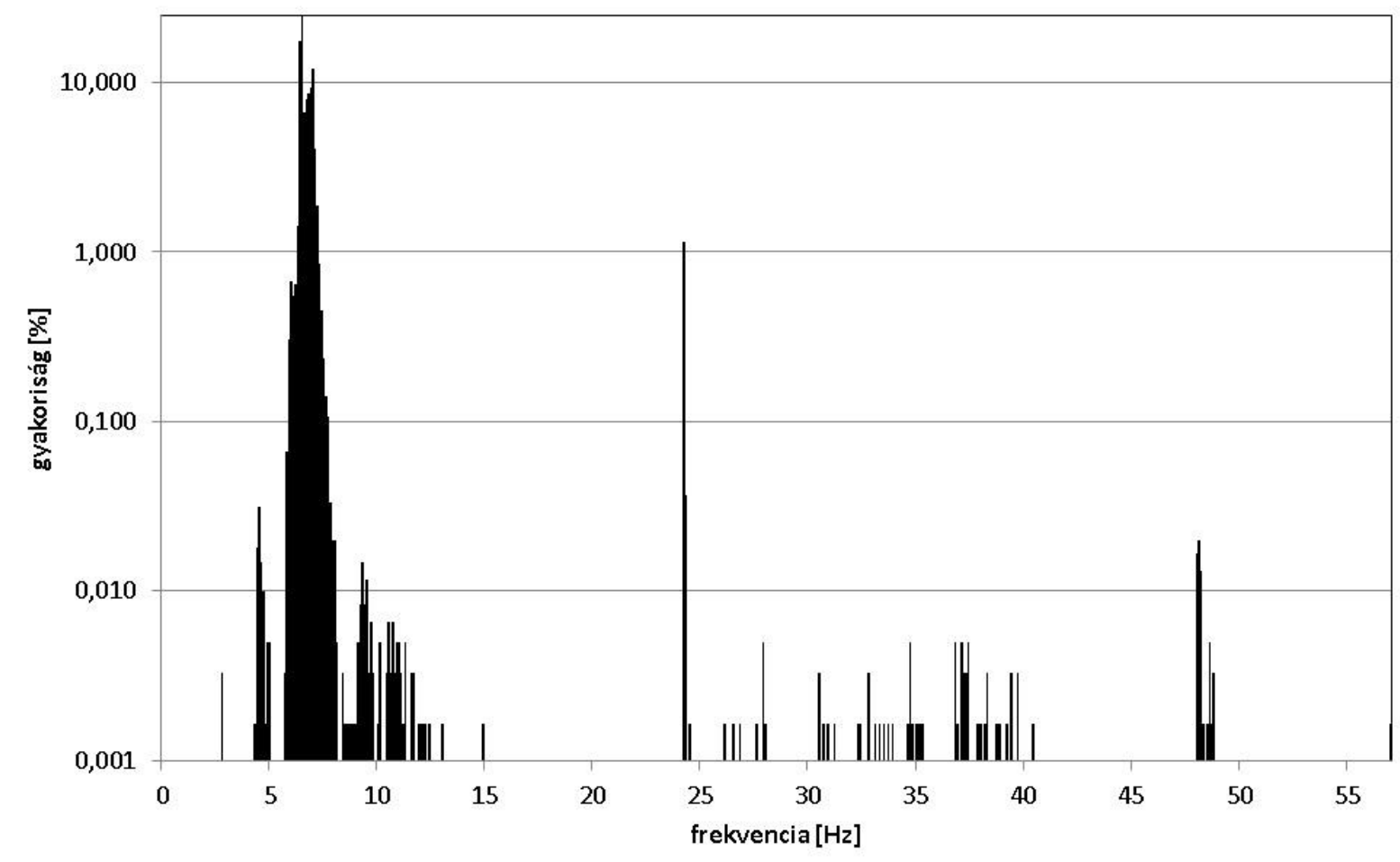

12. ábra. A tartófal rezgés $L D V$ spektrumainak maximális amplitúdóihoz tartozó frekvenciák eloszlása logaritmikus gyakorisági skálán. A gyakoriságot a 0,1 Hz osztással felvett hisztogramra vonatkoztattuk

A 12. ábra a tartófal rezgés LDV spektrumainak maximális amplitúdóihoz tartozó frekvenciáit szemlélteti. A gyakoriságot a $0,1 \mathrm{~Hz}$ osztással felvett hisztogramra vonatkoztattuk. A kis gyakoriságú frekvenciák ábrázolhatósága érdekében logaritmikus skálát alkalmaztunk. A logaritmikus skála ugyanakkor elrejtheti azt a tényt, hogy az összes adat kb. 98\%-a az 5,9-7,6 Hz frekvencia tartományba esik. A görbe csúcsa kettős $(6,5$ és 7,0 Hz), közöttük kis behorpadás van. Igen éles, bö 1\%-os gyakorisági csúcsot kaptunk 24,2 Hz-en. Ez a frekvencia egyetlen kb. kétórás időintervallumban (2021. július 15. (csütörtök) 
12.49-14.54) dominált, minden bizonnyal egy, valahol az épületben (de az adott fal közelében) bekapcsolt gép okozhatta. A lapos 35-40 Hz-es csúcsokat tanszéki fizikai aktivitás okozhatta (lásd 8. ábra), de zivatarok idején is dominált (talán a menydörgés is okozhatta). A 48-49 Hz-en látható pici csúcs néhány rövid periódusban jött, minden bizonnyal egy bekapcsolt gép okozta.

\section{4 Összefoglalás, következtetések}

A méréseink alapján megállapítható, hogy a tartófalak rezgésének 6-7 Hz körüli komponense nem lokális rezgés, hanem az egész épület rezgése. Ezt két tény is alátámasztja. Egyrészt ez a komponens megtalálható mindkét tartófal (amelyek a laboratórium szemben lévő oldalain vannak) rezgési spektrumában. Másrészt ezt a rezgést nem tudjuk a közelben végzett fizikai tevékenységekkel befolyásolni. Ez a rezgés folyamatosan jelen van, a méréseink több, mint 97\%-ában ez a legnagyobb amplitúdójú komponens. Ez nappal jelentősebb, erősen ingadozó komponens 0,003-0,006 $\mathrm{mm} / \mathrm{s}$ átlagértékkel, de egész éjszaka mérhető marad (stabilan kb. $0,001 \mathrm{~mm} / \mathrm{s}$ ).

A rezgést (távoli) emberi aktivitás és/vagy meteorológiai tényezők okozhatják. A kiváltó okok feltárása érdekében jelenleg is folynak a mérések. Az biztos, hogy a falak rezgését helyi fizikai aktivitással (ugrálás, futkosás) ki tudjuk váltani, de ezek nagyon különböznek az egész épület rezgésétől és az aktivitás befejezése után rögtön meg is szünnek.

\section{Irodalom}

[1] Béres, M., Paripás, B. (2017). Comparison of two laser interferometric methods for the study of vibrations. Lecture Notes in Mechanical Engineering, Part F12, 205-16. https://doi.org/10.1007/978-3-319-51189-4_20

[2] Castellini, P., Martarelli, M., Primo Tomasini, E. (2013). Laser Doppler vibrometry for structural dynamic characterization of rotating machinery. In Applied Mechanics and Materials, Trans Tech Publications Ltd, 538-43. https://www.scientific.net/AMM.415.538 (November 30, 2020). https://doi.org/10.4028/www.scientific.net/AMM.415.538

[3] Földrengések hatása épületekre. http://www.foldrenges.hu/index.php?option=com_cont.

[4] Loughridge, R., Abramovitch, D. Y. (2013). A tutorial on laser interferometry for precision measurements. In Proceedings of the American Control Conference, IEEE, 3686-3703. http://ieeexplore.ieee.org/document/6580402/ (September 3, 2019).

[5] ME Fizikai Intézet, Wigner FK, BME Atomfizikai Tanszék. (2014). Kiválósági Együttmüködési Program: Extrém Anyagok, Energiák és Technológiák - Az interferometriától a spektroszkópián át a plazmadiagnosztikáig.

[6] MSZ 18163-2:1998, Rezgésmérés. Az emberre ható környezeti rezgések vizsgálata építményekben. 1998. : 10.

[7] Paripás, B., Palásthy, B., Majár, J., Béres, M. (2019). Épület rezgések mérése lézerinterferometrikus módszerekkel. https://doi.org/10.26649/musci.2019.025 